\title{
Efektivitas Senam Mata untuk Mengurangi Tingkat Kelelahan Mata pada Pekerja Rambut Palsu
}

\author{
Febri Mahalinda Maisal ${ }^{1 *}$, Luh Putu Ruliati², Noorce Christiani Berek ${ }^{3}$, \\ Andreas Umbu Roga ${ }^{4}$, dan Jacob Matheos Ratu ${ }^{5}$ \\ 1,2,3,4,5) Program Studi Ilmu Kesehatan Masyarakat, Universitas Nusa Cendana, Kupang \\ ${ }^{*}$ e-mail korespondensi: febrimahalinda@gmail.com \\ doi: https://doi.org/10.24843/JEI.2020.v06.i01.p02 \\ Article Received: 31 Mei 2020; Accepted: 22 Juni 2020; Published: 30 Juni 2020
}

\begin{abstract}
Abstrak
Pembuatan rambut palsu membutuhkan ketelitian dan konsentrasi mata yang tinggi, karena memiliki objek kerja yang kecil dan dikerjakan secara monoton. Jika dilakukan dalam jangka waktu yang lama akan menimbulkan ketegangan pada otot mata, sehingga dapat menyebabkan kelelahan mata. Upaya untuk mencegah kelelahan mata yaitu dengan melakukan gerakan senam mata untuk meningkatkan kemampuan saraf dan otot mata. Penelitian ini bertujuan untuk menganalisis perbedaan nilai rerata kelelahan mata antara kelompok perlakuan dan kelompok kontrol terhadap penurunan tingkat kelelahan mata pada pekerja rambut palsu. Penelitian ini merupakan penelitan eksperimental dengan menggunakan randomized pre-posttest control group design. Penelitian dilaksanakan di CV. Dona Mandiri Kecamatan Kelapa Lima Kota Kupang. Populasi berjumlah 79 orang dan dilakukan acak alokasi untuk memilih subjek penelitian. Subjek penelitian berjumlah 17 orang pada kelompok perlakuan yang diberikan senam mata dan 17 orang pada kelompok kontrol tanpa diberikan senam mata. Tingkat kelelahan mata diukur menggunakan kuesioner kelelahan mata yang terdiri atas 10 pertanyaan tentang gejala kelelahan mata. Analisis data menggunakan uji T tidak berpasangan. Hasil penelitian menunjukkan bahwa ada perbedaan signifikan rerata kelelahan mata pada kelompok perlakuan dan kelompok kontrol sebesar 9,412 $(\mathrm{p}<0,05)$. Disimpulkan bahwa senam mata dapat mengurangi tingkat kelelahan mata pada pekerja rambut palsu.
\end{abstract}

Kata kunci: kelelahan mata, pekerja rambut palsu, senam mata

\section{The Effectiveness of Eye Exercises To Reduce The Level of Eye Fatigue among Wig Workers}

\begin{abstract}
Making wigs requires high eyes concentration and precission, because it has a work with small object and is done monotonously. If it is done for a certain period of time, it will cause tension in the eye's muscles, which can cause eyes fatigue. Efforts to prevent eyes fatigue were done by doing eye exercises in order to improve the ability of the nerves and eyes muscles. This study aimed to analyze the differences in the average value of eyes fatigue between the intervention group and the control group to reduce the level of eyes fatigue in the wig's workers. This research is an experimental study using randomized pre-posttest control group design. Research was conducted at CV. Dona Mandiri, Kupang City, with the population of 79 people and chosen by simple random allocation. The study subjects numbered 17 people in the intervention group and 17 people in the control group. The level of eye fatigue was measured using an eyes fatigue questionnaire consisting of 10 questions about symptoms of eyes fatigue. Data analysis using independent sample T-test. The results showed that the signifikan difference in the average value of eye fatigue in the intervention group and the control group
\end{abstract}


amounted to $9.412(p<0.05)$. It concluded that eyes exercises could reduce the level of eyes fatigue in wigs hair workers.

Keywords: eye exercises, eye fatigue, wig wokers

\section{PENDAHULUAN}

Majunya perkembangan teknologi di era globalisasi saat ini mendorong banyak perusahaan untuk mencapai tahap industri yang moderen dan berdampak bagi perkembangan ekonomi. Namun saat ini banyak sekali perusahaan yang hanya mengambil keuntungan dari hasil produksinya tanpa memperhatikan kesehatan dan juga keselamatan dari tenaga kerjanya sendiri. Akibatnya, tenaga kerja seringkali mengalami gangguan kesehatan dan bahkan mengalami kecelakaan saat kerja akibat pengaruh lingkungan kerja yang tidak ergonomis (Susanti, 2017) Data dari International Labour Organization (ILO, 2013) mencatat sekitar 1,2 juta pekerja di dunia meninggal disebabkan oleh penyakit akibat kerja (PAK) dan kecelakaan saat kerja. Setiap tahun terjadi lebih dari 250 juta kasus kecelakaan ditempat kerja dan lebih dari 160 juta mengalami penyakit akibat kerja (PAK).

Salah satu permasalahan Kesehatan dan Keselamatan Kerja (K3) yang dapat menjadi pemicu kecelakaan kerja adalah kelelahan. Kelelahan disebabkan karena seseorang bekerja dengan beban kerja dan lingkungan kerja yang seringkali menyebabkan menurunnya efisiensi dan ketahanan tubuh (Maharja, 2015). Word Health Organization (WHO) menjelaskan bahwa kelelahan merupakan penyebab kematian nomor dua setelah penyakit jantung yang dialami oleh tenaga kerja. Penelitian yang dilakukan oleh Kementerian Tenaga Kerja di Jepang terhadap 12 ribu perusahaan yang melibatkan sekitar 16 ribu tenaga kerja yang dipilih secara acak, menunjukan bahwa 65\% tenaga kerja mengeluh karena kelelahan fisik akibat pekerjaannya (Juliana, dkk., 2018). Kelelahan fisik dapat terjadi pada seluruh anggota tubuh, salah satunya pada mata. Kelelahan mata atau astenophia adalah gejala adanya gangguan sistem penglihatan yang disebabkan oleh upaya yang berlebihan dari fungsi mata yang berada dalam kondisi kurang sempurna untuk memperoleh ketajaman penglihatan pada suatu objek (Ilyas dan Yulianti, 2015)

Data menurut $W H O$ tahun 2010 terdapat 285 juta orang atau 4,24\% dari total populasi pekerja di dunia mengalami penurunan tajam penglihatan atau severe low vision. Data Riskesdas tahun 2013 menunjukkan bahwa prevalensi penurunan tajam penglihatan pada tenaga kerja di Indonesia pada usia produktif $15-54$ tahun sebesar 1,49\% dan prevalensi kebutaan sebesar $0,5 \%$. Sementara penurunan tajam penglihatan paling tinggi terdapat pada penduduk umur 45 tahun ke atas sesuai dengan proses degeneratif pertambahan usia seseorang, dengan rata-rata peningkatan sekitar 2 sampai 3 kali lipat setiap tahunnya. Severe low vison dengan prevalensi tertinggi menurut kategori pekerjaan yakni pada pekerja sektor informal sebesar 1,3\% (Maulina dan Syafitri, 2019).

Masalah kelelahan mata seringkali dijumpai pada pekerja sektor formal maupun informal yang seringkali tidak diperhatikan oleh pemilik perusahaan atupun pemerintah, untuk melakukan pemeliharaan kesehatan terhadap tenaga kerja. Salah satu pekerjaan di sektor informal yang sering berpotensi mengalami kelelahan mata yaitu pekerja rambut palsu. Pekerjaan ini memiliki objek kerja yang kecil, memiliki sifat kerja yang statis, dan dikerjakan dalam jangka waktu yang lama. Apabila tidak diperhatikan secara baik akan menimbulkan gangguan pada mata tenaga kerja (Wiyanti dan Martiana, 2017).

Perusahaan CV. Donna Mandiri merupakan industri pengolahan rambut palsu yang berlokasi di Kelurahan Lasiana, Kecamatan Kelapa Lima, Kota Kupang, Nusa Tenggara Timur. CV. Donna Mandiri mengontrak tujuh kamar kos untuk dijadikan tempat memproduksi rambut palsu. Setiap kamar atau ruangan terdiri dari dua meja yang berukuran besar. Setiap 
meja digunakan oleh 6-7 pekerja dan setiap meja didukung oleh tiga lampu sebagai sumber pencahayaan. Oleh karena ruang kerja terbatas, pekerja sering merasakan ketidaknyamanan saat bekerja dan diperparah dengan suhu ruangan yang menurut pekerja terlalu panas sehingga seringkali membuat mereka tidak fokus saat bekerja.

Posisi kerja juga menjadi salah satu faktor yang menyebabkan ketidaknyamanan saat bekerja karena lampu posisinya cukup dekat dengan kepala sehingga seringkali pekerja merasakan panas di daerah kepala yang disertai dengan pusing, dan penglihatan yang tidak fokus. Lama kerja pekerja rambut palsu dalam sehari yaitu 6-7 jam yang dilakukan secara monoton dengan sikap kerja yang statis. Selain itu objek kerja yang berukuran kecil juga menjadi salah satu faktor yang menyebabkan kelelahan mata pada pekerja rambut palsu.

Berdasarkan hasil wawancara menggunakan kuesioner kelelahan mata diperoleh bahwa dari 10 orang subjek yang diwawancarai semuanya mengalami kelelahan mata, dimana tujuh orang mengalami kelelahan mata berat dan tiga orang mengalami kelelahan mata sedang. Gejala yang sering dialami yaitu mata sering berair, terasa perih, kering, tegang, dan seringkali terlihat kabur sehingga tidak fokus ketika menyulam rambut palsu. Jika masalah ini dibiarkan tanpa adanya upaya pencegahan maka akan berdampak terhadap penurunan fungsi penglihatan dan bahkan dapat menyebabkan gangguan mata yang serius pada pekerja rambut palsu.

Kelelahan mata dapat dicegah dengan melakukan senam. Senam mata adalah upaya yang dilakukan untuk meningkatkan kemampuan mata, mempertajam penglihatan, membuat otot mata menjadi elastis dan kuat, serta dapat mempertajam penglihatan dengan beberapa gerakan tertentu yang dilakukan secara rutin (Noto, dkk., 2013). Penelitian yang dilakukan oleh (Sulistiyani, dkk., 2012) membuktikan bahwa senam mata berpengaruh untuk menurunkan kelelahan mata pada pekerja batik tulis. Penelitian ini bertujuan untuk menganalisis perbedaan kelelahan mata antara kelompok perlakuan dan kelompok kontrol terhadap penurunan tingkat kelelahan mata pada pekerja rambut palsu CV. Dona Mandiri Kecamatan Kelapa Lima Kota Kupang.

\section{METODE}

Penelitian ini merupakan penelitan eksperimental dengan menggunakan randomized pre-posttest control group design. Kelompok perlakuan diberikan perlakuan senam mata, kelompok kontrol tidak diberikan perlakuan. Penelitian ini berlokasi di CV. Dona Mandiri Kecamatan Kelapa Lima, Kelurahan Lasiana, Kota Kupang, yang berlangsung sejak Januari Februari 2020. Populasi penelitian berjumlah berjumlah 79 orang. Besar sampel ditentukan menggunakan rumus penentuan besar sampel (Sugiono, 2013). Sampel penelitian untuk setiap kelompok berjumlah 17 orang pada kelompok perlakuan dan 17 orang pada kelompok kontrol. Teknik pengambilan sampel yang digunakan yaitu menggunakan alokasi random yang bertujuan untuk menempatkan subjek penelitain pada kelompok perlakuan atau kelompok kontrol (Dahlan, 2013). Semua subjek memiliki beban yang sama antara kelompok perlakuan dan kelompok kontrol.

Penelitian ini dilakukan selama dua minggu dengan enam kali pertemuan. Setiap minggunya dilakukan tiga kali pertemuan pada hari selasa, rabu dan kamis. Pekerja rambut palsu memiliki lima hari kerja dalam seminggu, namun penelitian tidak dilakukan setiap hari karena pada hari jumat pekerja harus menghabiskan target mingguan. Sedangkan pada hari senin peneliti ingin membiarkan pekerja berinteraksi kembali dengan pekerjaannya setelah beristirahat selama dua hari untuk mendapatkan hasil kelelahan mata yang lebih akurat pada hari selanjutnya. Setiap pertemuan dilakukan empat kali perlakuan pada pukul 08:00 WITA, 10:00 WITA, 12:00 WITA, dan 15:00 WITA dengan tujuh gerakan yang berbeda dan setiap gerakan memiliki durasi waktu 5-10 detik (Jannah, 2012). Perlakuan senam mata dilakukan secara serentak bersama 17 orang kelompok perlakuan yang dipandu oleh peneliti. Proses 
pengambilan data pre-test kelelahan mata kedua kelompok dilakukan pada pertemuan pertama yang dilakukan pada awal minggu yaitu pada hari selasa sebelum pekerja melakukan aktivitas. Sedangkan pengambilan data post-test kelelahan mata kedua kelompok dilakukan pada pertemuan terakhir pada akhir minggu kedua penelitian ini yaitu pada hari kamis setelah pekerja melakukan aktivitas. Penelitian ini dibantu dengan leaflet tujuh gerakan senam mata untuk mempermudah pekerja dalam menghafal gerakan. Tujuh gerakan senam mata dapat dilihat pada Gambar 1.

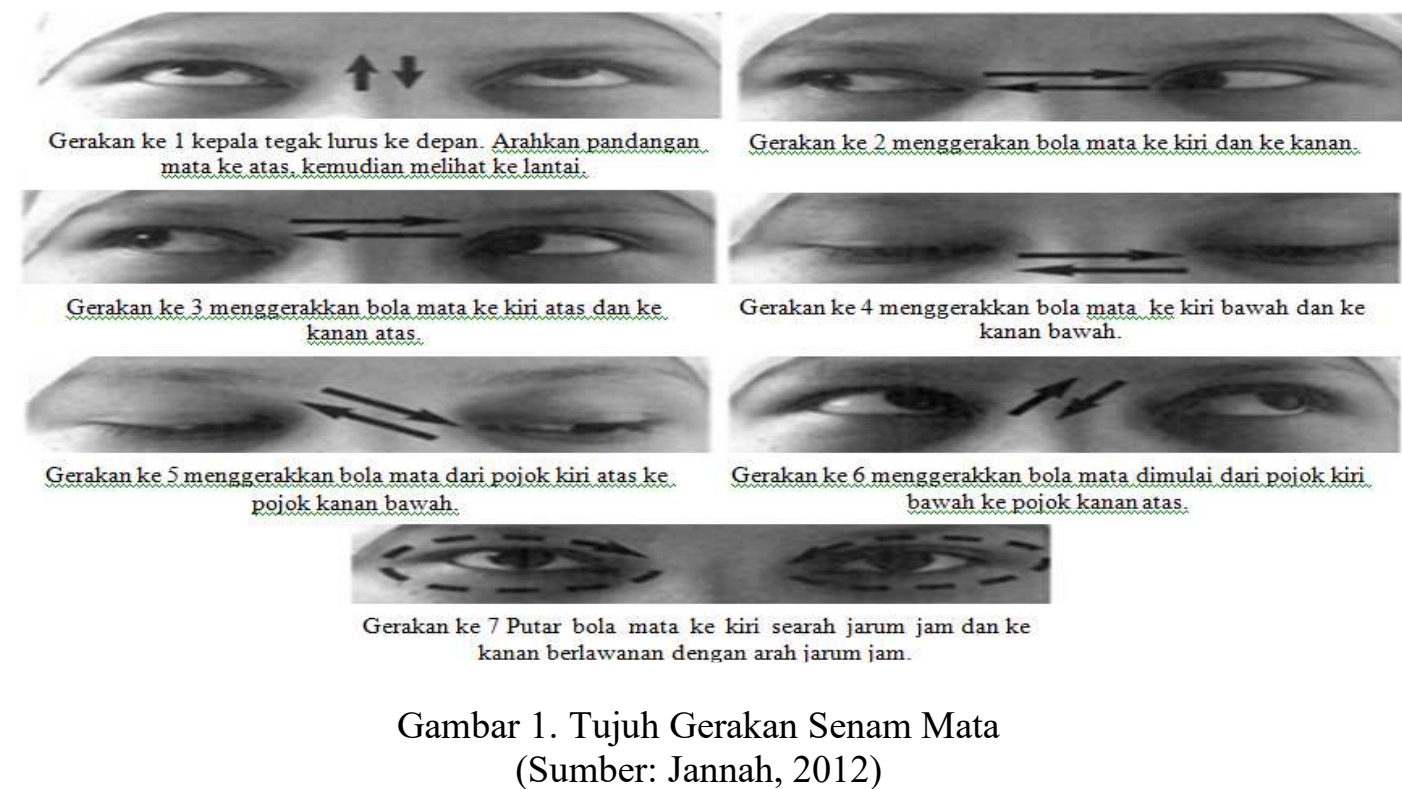

Tingkat kelelahan mata diukur berdasarkan empat kategori yaitu kategori kelelahan mata ringan 10-17, kategori kelelahan sedang 18-25, kategori kelelahan mata berat berat 26-33, dan kategori kelelahan mata sangat berat 34-40. Kelelahan mata pada pekerja rambut palsu diukur menggunakan kuesioner kelelahan mata yang diadopsi dari penelitian sebelumnya yang dilakukan oleh (Odi, 2017) yang terdiri dari 10 pertanyaan tentang gejala kelelahan mata yang telah valid.

Analisis data dalam penelitian ini menggunakan analisis univariat yang bertujuan untuk menjelaskan karakteristik subjek penelitian seperti umur dan masa kerja serta menjelaskan distribusi frekuensi dari data kelelahan mata (Notoatmodjo, 2012). Analisis data yang kedua menggunakan Uji T tidak berpasangan atau uji beda untuk mengetahui nilai rerata kelelahan mata kelompok perlakuan dan kelompok kontrol setelah melakukan senam mata terhadap penurunan tingkat kelelahan mata. Tahapan sebelum melakukan uji $\mathrm{T}$ yaitu harus melakukan uji normalitas data untuk mengetahui data terdistribusi normal atau tidak. Dan tahapan selanjutnya yaitu uji homogenitas untuk mengetahui varians data yang sama atau homogen. Hasil uji normalitas data kelelahan mata berdasarkan hasil pre-test dan post-test kelompok perlakuan dan kelompok kontrol terdistribusi normal. Begitu juga dengan uji homogenitas data kelelahan mata antara kelompok kontrol dan kelompok intervesni sebelum melakukan senam mata memiliki varians data yang homogen atau sama sehingga dapat dilakukan Uji T.

\section{HASIL DAN PEMBAHASAN}

CV. Donna Mandiri merupakan Perusahaan Penanaman Modal Asing (PMA) yang bergerak dibidang industri pengelolaan rambut palsu. CV. Donna Mandiri membagi sistem kerjanya dalam dua bagian yang berbeda yaitu sistem semi borong yang bertugas untuk menyulam atau menjahit rambut palsu dalam job kecil yang berukuran setengah kepala. Bagian 
yang kedua yaitu sistem borongan, pada sistem ini pekerja menyulam rambut palsu dalam jumlah besar yaitu satu kepala penuh. Masa kerja pada sistem semi borong yaitu kurang dari enam bulan, sedangkan di sistem borongan lebih dari enam bulan. Dalam penelitian ini semua pekerja berada pada sistem borongan karena memiliki masa kerja lebih dari enam bulan. Beban kerja yang diberikan pada pekerja sistem borongan yaitu mengerjakan job besar atau satu kepala penuh dengan target minimal 12 pis kepala/pis dalam sebulan atau 4 pis dalam seminggu, semakin banyak pis yang dikerjakan maka semakin banyak poin yang mereka kumpulkan untuk bisa mendapatkan bonus.

Hasil penelitian yang telah dilakukan pada pekerja pekerja rambut palsu CV. Donna Mandiri menunjukan karakteristik pekerja berdasarkan umur dan masa kerja. Karakteristik umur disajikam pada Tabel 1 dan karakteristik masa kerja disajikan pada Tabel 2.

Tabel 1

Distribusi Umur Pekerja Rambut Palsu CV. Donna Mandiri

Kecamatan Kelapa Lima Kota Kupang Tahun 2020

\begin{tabular}{ccccc}
\hline \multirow{2}{*}{$\begin{array}{c}\text { Umur } \\
\text { Tahun })\end{array}$} & \multicolumn{4}{c}{ Kelompok } \\
\cline { 2 - 5 } & \multicolumn{2}{c}{ Perlakuan } & \multicolumn{3}{c}{ Kontrol } \\
\cline { 2 - 5 } & Jumlah & $(\%)$ & Jumlah & $(\%)$ \\
\hline $20-25$ & 4 & 23,5 & 5 & 29,4 \\
$26-30$ & 7 & 41,2 & 8 & 47,1 \\
$31-35$ & 4 & 23,5 & 3 & 17,6 \\
$36-40$ & 2 & 11,8 & 1 & 5,9 \\
\hline Jumlah & 17 & 100 & 17 & 100 \\
\hline
\end{tabular}

Tabel 1 menunjukkan peresentase umur terbanyak, pada kelompok perlakuan adalah kelompok umur 26-30 tahun yaitu berjumlah 7 orang (41,2\%). Demikian juga pada kelompok kontrol, presentase umur terbanyak adalah kelompok umur 26-30 tahun yaitu sebanyak 8 orang $(47,1 \%)$.

Tabel 2

Distribusi Masa Kerja Pekerja Rambut Palsu CV. Donna Mandiri Kecamatan Kelapa Lima Kota Kupang Tahun 2020

\begin{tabular}{ccccc}
\hline Masa Kerja & \multicolumn{4}{c}{ Kelompok } \\
\cline { 2 - 5 } & \multicolumn{2}{c}{ Perlakuan } & \multicolumn{3}{c}{ Kontrol } \\
\hline & Jumlah & $(\%)$ & Jumlah & $(\%)$ \\
\hline$<2$ Tahun & 7 & 41,2 & 8 & 47,1 \\
$\geq 2$ Tahun & 10 & 58,8 & 9 & 52,9 \\
\hline Jumlah & 17 & 100 & 17 & 100 \\
\hline
\end{tabular}

Tabel 2 menunjukkan peresentase masa kerja terbanyak, pada kelompok perlakuan adalah pada kategori $\geq 2$ tahun yang berjumlah 10 orang $(58,8 \%)$. Demikian juga pada kelompok kontrol, presentase masa kerja terbanyak adalah pada kategori $\geq 2$ tahun yang berjumlah 9 orang $(52,9 \%)$.

Pada penelitian ini dilakukan analisis univariat untuk menggambarkan data kelelahan mata secara umum berdasarkan hasil pre-test dan post-test kelelahan mata pada kelompok perlakuan bertujuan untuk menampilkan tingkatan kelelahan mata yang dialami oleh pekerja rambut palsu sebelum dan sesudah melakukan senam mata. Data tingkat kelelahan mata pada 
kelompok perlakuan disajikan pada Tabel 3 dan data tingkat kelelahan mata pada kelompok kontrol disajikan pada Tabel 4.

Tabel 3

Distribusi dan Rerata Skor Kelelahan Mata Kelompok Perlakuan Pekerja Rambut Palsu CV. Donna Mandiri Kecamatan Kelapa Lima Kota Kupang Tahun 2020

\begin{tabular}{lccccccccc}
\hline Kelelahan & \multirow{2}{*}{ Interval } & \multicolumn{4}{c}{ Pre-Test } & \multicolumn{5}{c}{ Post-Test } \\
\cline { 2 - 10 } & & Jumlah & $(\%)$ & Rerata & SB & Jumlah & $(\%)$ & Rerata & SB \\
\hline Ringan & $10-17$ & 0 & 0 & & & 6 & 35,3 & & \\
Sedang & $18-25$ & 0 & 0 & 31,88 & 2,95 & 11 & 64,7 & 18,94 & 2,53 \\
Berat & $26-33$ & 12 & 70,6 & & & 0 & 0 & & \\
Sangat Berat & $34-40$ & 5 & 29,4 & & & 0 & 0 & & \\
\hline Jumlah & \multicolumn{3}{c}{17} & 100 & & & 17 & 100 & \\
\hline
\end{tabular}

$\mathrm{SB}=$ Simpang Baku

Tabel 3 menunjukkan nilai rerata pre-test kelelahan mata pada kelompok perlakuan sebesar 31,88, dan nilai rerata post-test kelelahan mata 18,94. Pengukuran pre-test dilakukan sebelum melakukan perlakuan senam mata pada pertemuan pertama. Pengukuran post-test dilakukan setelah dilakukannya perlakuan senam mata pada pertemuan terakhir atau pertemuan ke enam.

Tabel 4.

Distribusi dan Rerata Skor Kelelahan Mata Kelompok Kontrol Pekerja Rambut Palsu CV. Donna Mandiri Kecamatan Kelapa Lima Kota Kupang Tahun 2020

\begin{tabular}{lccccccccc}
\hline Kelelahan & \multirow{2}{*}{ Interval } & \multicolumn{4}{c}{ Pre-Test } & \multicolumn{5}{c}{ Post-Test } \\
\cline { 2 - 9 } & & Jumlah & $(\%)$ & Rerata & SB & Jumlah & $(\%)$ & Rerata & SB \\
\hline Ringan & $10-17$ & 0 & 0 & & & 0 & 0 & & \\
Sedang & $18-25$ & 0 & 0 & 30,71 & 2,28 & 0 & 0 & 28,35 & 1,61 \\
Berat & $26-33$ & 14 & 82,4 & & & 17 & 100 & & \\
Sangat Berat & $34-40$ & 3 & 17,6 & & & 0 & 0 & & \\
\hline Jumlah & & 17 & 100 & & & 17 & 100 & \\
\hline
\end{tabular}

$\mathrm{SB}=$ Simpang Baku

Tabel 4 menunjukkan nilai rerata pre-test kelelahan mata pada kelompok kontrol sebesar 30,71 dan nilai rerata post-test kelelahan mata 28,35. Hasil rerata pre-test dan post-test kelelahan mata pada kelompok kontrol mengalami penurunan namun tidak begitu jauh. Hal ini terjadi karena ada beberapa pekerja pada kelompok kontrol tidak menyelesaikan target yang diberikan karena alasan pribadi, sehingga mengerakan beban kerjanya tidak secara monoton seperti yang dilakukan oleh pekerja lainnya.

Perbedaan tingkat kelelahan mata antara kelompok perlakuan dan kelompok kontrol dianalisis menggunakan Uji T tidak berpasangan dengan derajat kepercayaan $95 \%(\alpha=0,05)$. Analisis ini bertujuan untuk mengetahui perbedaan tingkat kelelahan mata antara kelompok perlakuan setelah melakukan senam mata dan pada kelompok kontrol tanpa adanya perlakukan dan bekerja sama seperti biasanya. Perbedaan tingkat kelelahan mata berdasarkan hasil uji $\mathrm{T}$ tidak berpasangan kelompok perlakuan dan kelompok kontrol dapat disajikan pada Tabel 5.

Tabel 5 menunjukkan bahwa rerata pre-test kelelahan mata antara kelompok perlakuan dan kelompok kontrol tidak terdapat perbedaan yang signifikan dilihat dari selisih nilai kedua kelompok yang tidak jauh berbeda yaitu sebesar 1,176 dengan nilai $t=1,298<1,693$ dan nilai 
$\mathrm{p}=0,203(\mathrm{p}>0,05)$ sehingga dapat dikatakan bahwa kedua kelompok berada pada tingkat kelelahan yang sama sebelum melakukan perlakuan senam mata. Hasil pre-test ini membuktikan bahwa kedua kelompok memiliki data kelelahan mata yang bersifat homogen.

Tabel 5

Perbedaan Tingkat Kelelahan Mata pada Kelompok Perlakuan dan Kelompok Kontrol Pekerja Rambut Palsu CV. Donna Mandiri Kecamatan Kelapa Lima Kota Kupang Tahun 2020

\begin{tabular}{|c|c|c|c|c|c|c|}
\hline \multirow{2}{*}{ Data } & \multicolumn{2}{|c|}{ Rerata } & \multirow{2}{*}{$\begin{array}{c}\text { Selisih } \\
\text { Nilai }\end{array}$} & \multirow{2}{*}{$\begin{array}{l}\text { Nilai t } \\
\text { Hitung }\end{array}$} & \multirow{2}{*}{$\begin{array}{l}\text { Nilai t } \\
\text { Tabel }\end{array}$} & \multirow[b]{2}{*}{$\mathrm{p}$} \\
\hline & Perlakuan & Kontrol & & & & \\
\hline Pre-Test & 31,88 & 30,71 & 1,176 & 1,298 & 1,693 & 0,203 \\
\hline Post-Test & 18,94 & 28,35 & 9,412 & 12,898 & 1,693 & 0,000 \\
\hline
\end{tabular}

Sementara rerata post-test kelelahan mata antara kelompok perlakuan dan kelompok kontrol memiliki perbedaan dilihat dari selisih nilai kedua kelompok yaitu sebesar 9,412 dengan dengan nilai $\mathrm{t}=12,898>1,693$ dan nilai $\mathrm{p}<0,05$ yang artinya kedua kelompok memiliki tingkat kelelahan mata yang berbeda.

Tabel 6

Uji Beda Selisih Nilai Rerata Kelelahan Mata pada Kelompok Perlakuan dan Kelompok Kontrol pada Pekerja Rambut Palsu CV. Donna Mandiri Kecamatan Kelapa Lima Kota Kupang Tahun 2020

\begin{tabular}{|c|c|c|c|c|c|}
\hline \multirow[t]{2}{*}{ Kelompok } & \multicolumn{2}{|c|}{$\begin{array}{c}\text { Rerata } \\
\text { Kelelahan Mata }\end{array}$} & \multirow[t]{2}{*}{ Selisih Nilai } & \multirow{2}{*}{$\begin{array}{l}\text { Beda Selisih } \\
\text { Nilai }\end{array}$} & \multirow{2}{*}{$\mathrm{p}$} \\
\hline & Pre-test & Post-test & & & \\
\hline Perlakuan & 31,88 & 18,94 & 12,941 & \multirow{2}{*}{10,588} & \multirow{2}{*}{0,000} \\
\hline Kontrol & 30,71 & 28,35 & 2,353 & & \\
\hline
\end{tabular}

Tabel 6 menunjukkan selisih nilai rerata pre-test dan post-test kelelahan mata pada kelompok perlakuan dan kelompok kontrol. Selisih nilai rerata pre-test dan post-test kelompok perlakuan yaitu sebesar 12,941. Sedangkan pada kelompok kontrol selisih nilai rerata pre-test dan post-test sebesar 2,353. Hasil uji beda selisih nilai pre-test dan post-test kedua kelompok juga menunjukkan bahwa adanya perbedaan selisih nilai sebesar 10,588 secara signifikan $(\mathrm{p}<0,05)$. Berdasarkan uji beda selisih ini membuktikan bahwa senam mata berpengaruh menurunkan tingkat kelelahan mata pada pekerja rambut palus.

Hasil penelitian ini menunjukan bahwa adanya perbedaan nilai rerata dan beda selisih nilai rerata kelelahan mata antara kedua kelompok, sehingga membuktikan bahwa, senam mata berpengaruh terhadap penurunan tingkat kelelahan mata pada pekerja rambut palsu. Dengan melakukan senam mata empat kali sehari secara rutin dan dilakukan dalam enam kali pertemuan, kelompok perlakuan mengalami penurunan nilai rerata kelelahan mata yang signifikan dibandingkan kelompok kontrol, sehingga selisih nilai rerata antara kedua kelompok berbeda secara signifikan. Hasil penelitian ini sejalan dengan penelitian yang dilakukan oleh Joshi dan Retharekar (2017) menjelaskan bahwa upaya untuk meningkatkan kesehatan mata yaitu dengan melakukan terapi senam. Senam mata dijelaskan mampu meningkatkan kemampuan mata, mempertajam penglihatan, membuat otot mata menjadi elastis dan kuat, serta dapat mempertajam penglihatan.

Senam mata merupakan salah satu upaya pencegahan yang paling efektif dan efisien untuk mengurangi kelelahan mata yang dialami oleh pekerja rambut palsu, karena senam mata mudah dilakukan dan tidak membutuhkan tempat yang khusus, biaya yang banyak, dan waktu 
yang lama. Hasil penelitian menunjukan bahwa keluhan kelelahan mata yang dialami pekerja rambut palsu membaik setelah mereka melakukan senam mata setelah enam kali pertemuan. Senam mata dapat menurunkan kelelahan mata karena gerakan-gerakan senam mata mampu mengembalikan daya elasistisitas otot-otot akomodasi mata dan menurunkan stress intensif pada fungsi mata. Pekerja merasa merasa bahwa gangguan pada mata mereka berkurang dan lebih membaik ketika mereka melakukan senam mata secara rutin. Hasil penelitian ini sejalan dengan penelitian yang dilakukan oleh Sulistiyani dkk. (2012) yaitu senam mata dapat mengurangi tingkat kelelahan mata pada pekerja bulu mata palsu di Desa Pegadengan yang dilakukan dalam empat kali pertemuan.

Kelelahan mata merupakan gangguan pada fungsi penglihatan yang disebabkan oleh penggunaan indera penglihatan yang dipaksakan bekerja dalam jangka waktu yang lama sehingga menimbulkan stres intensif pada otot-otot akomodasi mata. Kelelahan mata biasanya ditandai dengan pandangan yang tidak nyaman dan tidak terfokus pada suatu objek tertentu (Suma'mur, 2014).

Kelelahan mata yang dialami pekerja rambut palsu dapat diakibatkan oleh faktor pekerjaan dan juga faktor individu. Faktor pekerjaan yang dimaksud seperti jenis pekerjaan atau objek kerja. Menurut Ilyas dan Yulianti (2015) ketegangan pada otot mata dapat terjadi jika mata dipaksakan untuk fokus pada suatu objek dengan durasi waktu yang lama dan dilakukan secara monoton atau berulang. Kelelahan mata yang dialami oleh pekerja rambut palsu diakibatkan oleh mata yang dipaksakan bekerja secara berlebih pada objek kerja yang berukuran kecil dan dikerjakan secara monoton sehingga mengakibatkan penurunan daya akomodasi pada otot mata yang menyebabkan gangguan pada fungsi penglihatan.

Berdasarkan hasil penelitian pekerja rambut palsu baik kelompok perlakuan mupun kelompok kontrol sering mengalami gejala kelelahan mata seperti mata sering berair, terasa perih, kering, tegang, dan sering kali terlihat kabur sehingga tidak fokus ketika menyulam rambut palsu. Namun setelah melakukan senam mata pada kelompok perlakuan keluhan kelelahan mata yang dialami tidak separah keluhan sebelumnya, hal ini dibuktikan dari hasil penelitian bahwa setelah melakukan senam mata kelompok perlakuan hanya mengalami kelelahan sedang dan ringan saja. Sebaliknya pada kelompok kontrol keluhan kelelahan mata masih sama seperti sebelumnya bahkan semua pekerja pada kelompok ini masih mengalami kelelahan mata berat.

Faktor penyebab lain dari kelelahan mata pada pekerja rambut palsu yaitu faktor individu seperti umur dan masa kerja. Menurut Tarwaka (2015), kemampuan fisik seseorang akan mengalami peningkatan sampai mencapai umur 25-30 tahun. Namun kemampuan tersebut tersebut akan menurun mengikuti pertambahan umur seseorang. Hal ini juga terjadi pada pekerja rambut palsu bahwa $44,1 \%$ pekerja berada pada kemampuan fisik yang mencapai puncaknya yaitu berumur 26-30 tahun. Ketika melakukan penelitian banyak pekerja yang mengeluh terhadap kelelahan mata yang dialami, terlebih pekerja yang tidak muda lagi. Hal ini menyebabkan mereka susah untuk fokus terhadap pekerjaannya. Diperparah dengan tidak diperbolehkannya penggunaan kacamata untuk membantu penglihatan, membuat sebagian pekerja mengalami kesulitan saat bekerja.

Hasil wawancara secara pribadi dengan pekerja rambut palsu, mengatakan bahwa fungsi penglihatan mereka menurun setelah menyulam rambut palsu. Menurut mereka pekerjaan ini tetap dilakukan untuk memenuhi kebutuhan ekonomi dari masing-masing individu, sehingga membuat mereka tetap bekerja tanpa memperhatikan efek dari gejala kelelahan mata yang dialami. Hasil penelitian ini didukung juga oleh teori yang dikemukakan oleh Jannah (2012), bahwa dengan melakukan senam mata dapat membuat otot mata dan sekitarnya menjadi elastis dan kuat, serta mempertajam penglihatan dan meningkatkan fungsi mata. Semakin sering kita melakukan senam mata maka akan menguatkan otot-otot pada mata agar mengembalikan fungsi penglihatan menjadi lebih baik. 
Produktivitas kerja yang baik merupakan salah satu tujuan utama yang ingin dicapai CV. Donna Mandiri, baik itu pemiliknya untuk medapatkan keuntungan atau bagi tenaga kerjanya untuk mendapatkan upah. Namun melihat keadaan yang terjadi bahwa adanya masalah kesehatan yang di alami pekerja membuat pekerja sering kali tidak bisa mencapai target yang ditetapkan karena berbagai keluhan kelelahan mata yang dialami. Tetapi ada juga pekerja yang meskipun mengalami gangguan pada kesehatan mata mereka tetap memaksakan diri untuk tetap bekerja demi mencapai taget dan juga demi mendapatkan bonus. Untuk itu senam mata dianggap membantu untuk mengembalikan ketajaman penglihatan mereka, dibuktikan dari tingkat kelelahan mata yang dialami oleh kelompok perlakuan yang menurun secara signifikan setelah melakukan senam mata. Hal ini tentunya akan berdampak baik bagi produktivitas kerja mereka agar dapat mencapai target yang diberikan karena adanya upaya senam mata yang dialkukan untuk mencegah kelelahan mata yang akan berdampak pada peroduktivitas kerja. Hal ini didukung oleh penelitian yang dilakukan oleh Lertwisuttipaiboon dkk. (2017) bahwa perlakuan senam mata dapat menurunkan ketegangan mata pada staf atau pengguna komputer di Thailand sehingga dapat mengembalikan produktivitas kerja.

\section{SIMPULAN}

Senam mata berpengaruh terhadap penurunan tingkat kelelahan mata pada pekerja rambut palsu dilihat dari adanya perbedaan nilai rerata kelelahan mata yang signifikan antara kelompok perlakuan dan kelompok kontrol terhadap penurunan tingkat kelelahan mata pada pekerja rambut palsu CV. Donna Mandiri. Untuk itu perlu menjadi perhatian kepada pemilik perusahaan dan tenaga kerjanya untuk lebih memperhatikan manfaat dari penelitian ini. Senam mata dapat dijadikan sebagai kegiatan wajib dan rutin bagi semua pekerja rambut palsu agar dapat terhindar dari kelelahan mata sehingga dapat meminimalisir kecelakaan saat bekerja. Dengan melakukan senam mata secara rutin pekerja rambut palsu dapat meningkatkan dan mempertajam penglihatan sehingga lebih produktif untuk menghasilkan rambut palsu.

\section{DAFTAR PUSTAKA}

Dahlan, M.S. 2013. Besar Sampel dan Cara Pengambilan Sampel. Jakarta: Salemba Medika. ILO. 2013. Keselamatan Dan Kesehatan Kerja: Sarana Untuk Produktivitas. Clinics in Laboratory Medicine, Vol. 33(1):125-137. https://doi.org/10.1016/j.cll.2012.10.002.

Ilyas, S., dan Yulianti, S. 2015. Ilmu Penyakit Mata (5th ed). Jakarta: Badan Penerbit FKUI. Jannah, R. 2012. Gangguan Kesehatan Mata. Guepedia.

Joshi, H., dan Retharekar, S. 2017. The effect of eye exercises on visual acuity and refractive error of myopics. International Journal of Therapies and Rehabilitation Research, Vol. 6(3):249. https://doi.org/10.5455/ijtrr.000000274.

Juliana, M., Camelia, A., dan Rahmiwati, A. 2018. Analisis Faktor Risiko Kelelahan Kerja Pada Karyawan Risk Factor Analiysis For Fatigue in Production Departement Employes Of PT. Arwana Anugrah Keramik, Tbk. Jurnal Ilmu Kesehatan Masyarakat, Vol. 9(1):53-63.

Lertwisuttipaiboon, S., Pumpaibool, T., Neeser, K. J., dan Kasetsuwan, N. 2017. Effectiveness of a participatory eye care program in reducing eye strain among staff computer users in Thailand. Risk Management and Healthcare Policy, Vol. 10:71-80. https://doi.org/10.2147/RMHP.S134940.

Maharja, R. 2015. Analisis Tingkat Kelelahan Kerja Berdasarkan Beban Kerja Fisik Perawat Di Instalasi Rawat Inap RSU Haji Surabaya. The Indonesian Journal of Occupational Safety and Health, Vol. 4(1):93. https://doi.org/10.20473/ijosh.v4i1.2015.93-102. 
Maulina, N., dan Syafitri, L. 2019. Dengan Keluhan Kelelahan Mata Pada Penjahit Sektor Usaha Informal Di Kecamatan Banda Sakti Kota Lhokseumawe Tahun 2018. Jurnal Averrous, Vol. 5(2):44-58.

Noto, P. Di, Uta, S., dan DeSouza, J. F. X. 2013. Eye Exercises Enhance Accuracy and Letter Recognition, but Not Reaction Time, in a Modified Rapid Serial Visual Presentation Task. PLOS One Cognitive Neuroscience Channel, Vol. 8(3):1-9.

Notoatmodjo, S. 2012. Metodologi Penilitian Kesehatan. Jakarta: Rineka Cipta.

Odi, K. 2017. Hubungan Sikap Kerja, Pencahayaan dan Suhu terhadap Kelelahan Kerja dan Kelelahan Mata pada Penjahit Kampung Solor Kupang.

Sugiono. 2013. Penelitian Kuantitatif, Kualitatif dan R dan D. Jakarta: Alfabeta.

Sulistiyani, A.T., Linggardini, K., dan Suswari, Y. 2012. Effectiveness of Eye Stretch To Reduce Eye Tiredness Level on False Eyelash. Jurnal Imiah Ilmu-Ilmu Kesehatan, Vol 12(3):20-24.

Suma'mur. 2014. Higiene Perusahaan dan Keselamatan Kerja. Jakarta: Sagung Seto.

Susanti, N.H.D. 2017. Pengaruh Eye Exercises Terhadap Mata Lelah Pada Mahasiswa Program Studi Ilmu Keperawatan (PSIK) 2013 Universitas Muhammadiyah Malang. Universitas Muhammadiyah Malang. http://eprints.umm.ac.id/id/eprint/41758

Tarwaka. 2015. Keselamatan dan Kesehatan Kerja Manajemen dan Implementasi K3 di Tempat Kerja. Harapan Press.

Wiyanti, N., dan Martiana, T. 2017. Hubungan Intensitas Penerangan Dengan Kelelahan Mata Pada Pengrajin Batik Tulis. The Indonesian Journal of Occupational Safety and Health, Vol. 4(2):144. https://doi.org/10.20473/ijosh.v4i2.2015.144-154. 